\title{
Acute toxicity study and behavioural response of Indian minor carp Labeo bata by the exposure of nonylphenol ethoxylate
}

\author{
K. Roy ${ }^{*}$, D.K. Mandal ${ }^{2}$ \\ ${ }^{1,2}$ Department of Zoology, School of Life Sciences, Visva-bharati (A central University), Santiniketan, India \\ *Corresponding Author: roykou86@gmail.com Mobile: 8116498773
}

Available online at: www.isroset.org

Accepted: 17/Aug/2018, Online: 30/Aug/ 2018

\begin{abstract}
Nonylphenol ethoxylate (NPE), a member of alkylphenol ethoxylates (APEs) is a toxic xenobiotic compound and non-ionic surfactants. It is used widely as a raw material for processing and cleaning in so many factories, mills and industries. In the present study, median lethal concentration $\left(\mathrm{LC}_{50}\right)$ of NPE was monitored in the Indian minor carp Labeo bata through probit analysis method. Behavioural responses were also observed in this fish upto 96 hours experimental period with the exposure of NPE. The $\mathrm{LC}_{50}$ value of NPE was followed as $4.90 \mathrm{mg} \mathrm{L}^{-1}, 4.79 \mathrm{mg} \mathrm{L}^{-1}, 4.68 \mathrm{mg} \mathrm{L}^{-1}$ and $4.47 \mathrm{mg} \mathrm{L}^{-1}$ at $24 \mathrm{~h}, 48 \mathrm{~h}$, $72 \mathrm{~h}$ and $96 \mathrm{~h}$ respectively for the fish $L$. bata. In the exposed fishes, excessive mucous secretion was observed over the body surface and also various type of behavioural changes were followed as suffocation, erratic swimming opening of mouth and gill, lethargic movement upward and downward movement and gulping before death. NPE is moderately toxic to the fish L.bata according to its $\mathrm{LC}_{50}$ values. Behavioural modifications were considered as a stress marker for the Indian minor carp L.bata with the exposure of NPE.
\end{abstract}

Keywords: Nonylphenol ethoxylate, Median lethal concentration, Behaviour, Labeo bata

\section{INTRODUCTION}

Nonylphenol ethoxylate (NPE) is a member of alkylphenol ethoxylates (APEs) family. The synthesis of NPE as a monomer in polymer production may help by a large number of isomeric compound of nonylphenol (NP). NPEs are non-ionic surfactants which are produced as raw material for production of many useful commodities like plastics, detergents, emulsifiers, pesticides, industrial and consumer cleaning products, personal-care products, textile processing, pulp and paper processing, metal and mineral processing, latex paints, wetting agents, foaming agents, inks, adhesives, and pharmaceuticals [1,2]. It contaminates environment through domestic as well as industrial sewage discharges [3]. Its degradation product of NP is the most critical metabolite of APEs due to its resistance to biodegradation, ability to bioaccumulation and its toxicity [4, 5, 6]. However, NP is found a lot in different environmental sites such as surface water, groundwater, air, soil, sediment, sewage sludge and effluents from sewage treatment. Nonylphenol ethoxylate breakdowns to the 4-nonylphenol as more stable and persistent in the aquatic environment [7]. The concentration of NP was recorded between 2 to $336 \mu \mathrm{g} \mathrm{L}^{-1}$ in British rivers [3], 0.3 to $45 \mu \mathrm{g} \mathrm{L}^{-1}$ in Swiss rivers [5] and 3 to $300 \mu \mathrm{g} \mathrm{L}{ }^{-1}$ in Canadian rivers [8]. NP concentration in sewage effluent was found upto $12 \mathrm{mg} \mathrm{L}^{-1}$ in USA [9].

The lethal concentration of NP was determined $0.032 \mathrm{ml} \mathrm{L}^{-1}$ in Oreochromis niloticus [7]. NP is found to be toxic for fish as indicated in its $\mathrm{LC}_{50}$ value $0.135 \mathrm{mg} \mathrm{L}^{-1}$ for fathead minnow [10] and $1.4 \mathrm{mg} \mathrm{L}^{-1}$ for Japanese Medaka [11]. The median lethal concentration (96 hours) of NP was followed as $0.89 \mathrm{mg} \mathrm{L}^{-1}\left(890 \mu \mathrm{g} \mathrm{L}^{-1}\right)$ for the fish Etroplus maculatus through probit analysis method [12]. Sublethal exposure of NP caused loss of equilibrium, lethargy and haemorrhagic alteration in fathead minnows after exposure to 98 and $187 \mu \mathrm{g} \mathrm{L}^{-1}$ respectively for 96 hours [10]. The potential risk of NP as endocrine disrupter was reported for fishes $[13,14,15]$. Number of acute and chronic toxicity study was reported for NP in aquatic organisms. Fishes was considered as the most vulnerable species to contaminated water after being exposed through gills, skin or food. In the present study, Indian minor carp Labeo bata was chosen for model organism to calculate the median lethal concentration $\left(\mathrm{LC}_{50}\right)$ of nonylphenol ethoxylate upto 96 hours through probit analysis method [16]. Therefore, it is a potential experimental model fish for biological research in India. The behavioural studies of aquatic organisms have become predominant in recent years with toxicological point of view. Behavioural alterations have been considered as a signal of stress conditions in animals when exposed to toxicants. Therefore the present study was also concentrated the behavioural response of Labeo bata with the exposure of NPE. Behavioural response in aquatic toxicology delivers an appreciated tool for acute toxicity assessment of nonylphenol ethoxylate in Labeo bata. 


\section{MATERIALS AND METHODS}

\section{Test chemical}

Technical grade nonylphenol ethoxylate (CAS NO-104-40-5) was purchased from Lobachemie Pvt. Ltd, Mumbai, India. The chemical was dissolved by absolute ethanol prior to application in experimental aquarium. Each concentration of NPEs was diluted with $2 \mathrm{ml}$ absolute ethanol in each aquarium.

\section{Fish maintenance and experimental condition}

Adult specimen of Labeo bata (length $20 \pm 2.3 \mathrm{~cm}$; weight $75 \pm 2.3 \mathrm{~g}$ ) was purchased from local fish farm in Birbhum $\left(23.67^{\circ} \mathrm{N}\right.$ $\left.87.72^{\circ} \mathrm{E}\right)$, West-Bengal, India. The fishes were acclimatized in the laboratory in constant aeration with natural light/dark cycle $(13 \mathrm{~L} / 11 \mathrm{D})$ and water temperature at $23 \pm 1^{\circ} \mathrm{C}$ for 15 days prior to experiment. The fishes were provided commercially available feed pellet (Tokyu) and clean the aquarium daily to recycle water through filter pump. Healthy, disease free fishes were kept in $60 \mathrm{~L}$ capacity glass aquarium containing $40 \mathrm{~L}$ water in each. Each aquarium containing 10 fishes were handled carefully when experiment was conducted. The physico-chemical parameters of usable aquarium water was determined by the method [17] and the parameters were as follows: $\mathrm{pH} 7.58 \pm 0.2$, dissolve oxygen content $6.76 \pm 0.11 \mathrm{mg} \mathrm{L}^{-1}$, total alkalinity $162.08 \pm 1.56 \mathrm{mg}$ $\mathrm{L}^{-1}$ and total hardness $165.1 \pm 2.18 \mathrm{mg} \mathrm{L}^{-1}$.

\section{Experimental design}

The static toxicity tests were performed upto 96 hours to estimate median lethal concentration $\left(\mathrm{LC}_{50}\right)$ value. The experiment was performed by taking 11 aquariums among which one was kept as control and rests were contaminated with NPE at different concentrations. The test fishes (10 fishes per tank) were exposed to different concentrations of NPE as follows: $3,3.5$, 4, 4.5, 5, 5.5, 6, 6.5, 7 and $7.5 \mathrm{mg} \mathrm{L}^{-1}$. The NPE was dissolved in absolute ethanol before adding into aquarium. The volume of absolute ethanol was same for each aquarium including control group. In every four hours the experimental aquariums were observed and mortality was recorded. Each dead fishes were removed immediately from the aquarium to avoid contamination. The cumulative data dose and mortality response for 96 hours were recorded for each group and subjected to estimate 96 hours $\mathrm{LC}_{50}$ value of NPE following probit analysis method [16]. The mortality with behavioural changes of fishes in each group was monitored in control as well as exposed fishes throughout the experiment.

\section{Calculation of $\mathrm{LC}_{50}$ value}

The mortality response of fish against each concentration of NPE was estimated (Table 1). NPE concentrations (mg L $\mathrm{L}^{-1}$ ) were converted to $\log$ concentration (X) and mortality percentage of fish during 96 hours exposure were converted to empirical probit value (Y) with the help of Finney's table. The mortality responses $>0$ to $<100 \%$ were considered for calculation. Deviation of $(\mathrm{x})=\mathrm{X}-\mathrm{X}$ for $\log$ concentration and deviation of $(\mathrm{y})=\mathrm{Y}-\mathrm{Y}$ for probit value mortality were determined and finally linear regression value (b) was calculated with the formula $b=\sum x y / \sum x^{2}$ (Table 1). Empirical probit value (Y) and log concentration of NPE were plotted in Y and X axis respectively. Three corresponding linear values of $\mathrm{X}$ and $\mathrm{Y}$ were determined with the regression value (b) using the formula $\mathrm{Y}-\mathrm{Y}=\mathrm{b}(\mathrm{X}-\mathrm{X})$ and plotted in the graph to obtain a straight line (Figure 1). The corresponding coordinate of the empirical probit value 5 was obtained as $\log \mathrm{LC}_{50}$ concentration and the antilog of that value was considered as the 96 hours $\mathrm{LC}_{50}$ value of NPE for the fish Labeo bata.

\section{Statistical analysis}

The median lethal concentration was calculated by the probit analysis statistical method and linear regression curve was drawn using MS Excel 2010. The best-fit line was represented through correlation between mortality percentage on the Y-axis and log concentration of NPE on X-axis. The hydrological parameters, fish length and weight were calculated with mean \pm standard deviation (SD).

\section{RESULT}

\section{Mortality response and calculation of linear regression}

In this experiment mortality of fishes were continuously monitored in each group upto 96 hours and observed control and $3 \mathrm{mg}$ $\mathrm{L}^{-1}$ concentration of NPE was not mortality throughout the experimental period. At the concentrations $3.5,4,4.5,5,5.5$ and 6 $\mathrm{mg} \mathrm{L}^{-1} \mathrm{NPE}$ was observed death of 4, 4, 5, 5, 6 and 8 fishes respectively at the end of 96 hours exposure. However all fishes were death at the concentration level $6.5 \mathrm{mg} \mathrm{L}^{-1}$ at the end of 96 hours experiment. 
Dose and mortality responses of Labeo bata after 96 hours exposure to nonylphenol ethoxylate is tabulated in table 1 . No mortality was observed at a concentration below $3 \mathrm{mg} \mathrm{L}^{-1}$ and $100 \%$ mortality was observed in the concentration above $6.5 \mathrm{mg}$ $\mathrm{L}^{-1}$. A regression value of probit mortality percentages and log concentrations of NPE exposure was estimated as 4.29 using the formula (b) $=\sum x y / \sum x^{2}$. With the help of regression value, a linear curve of dose mortality response was obtained as Figure 1 . From the curve the corresponding coordinate of the empirical probit value $5\left(\mathrm{LC}_{50}\right)$ was obtained at log concentration 0.65 of NPE. Thus, $\mathrm{LC}_{50}$ value was calculated as the antilog of 0.65 which was $4.47 \mathrm{mg} \mathrm{L}^{-1}$. Therefore, 96 hours LC 50 value is $4.47 \mathrm{mg}$ $\mathrm{L}^{-1}$ of NPE for the Indian minor carp Labeo bata.

Table 1. Mortality response of Labeo bata after 96 hour exposure to different concentrations of NPE

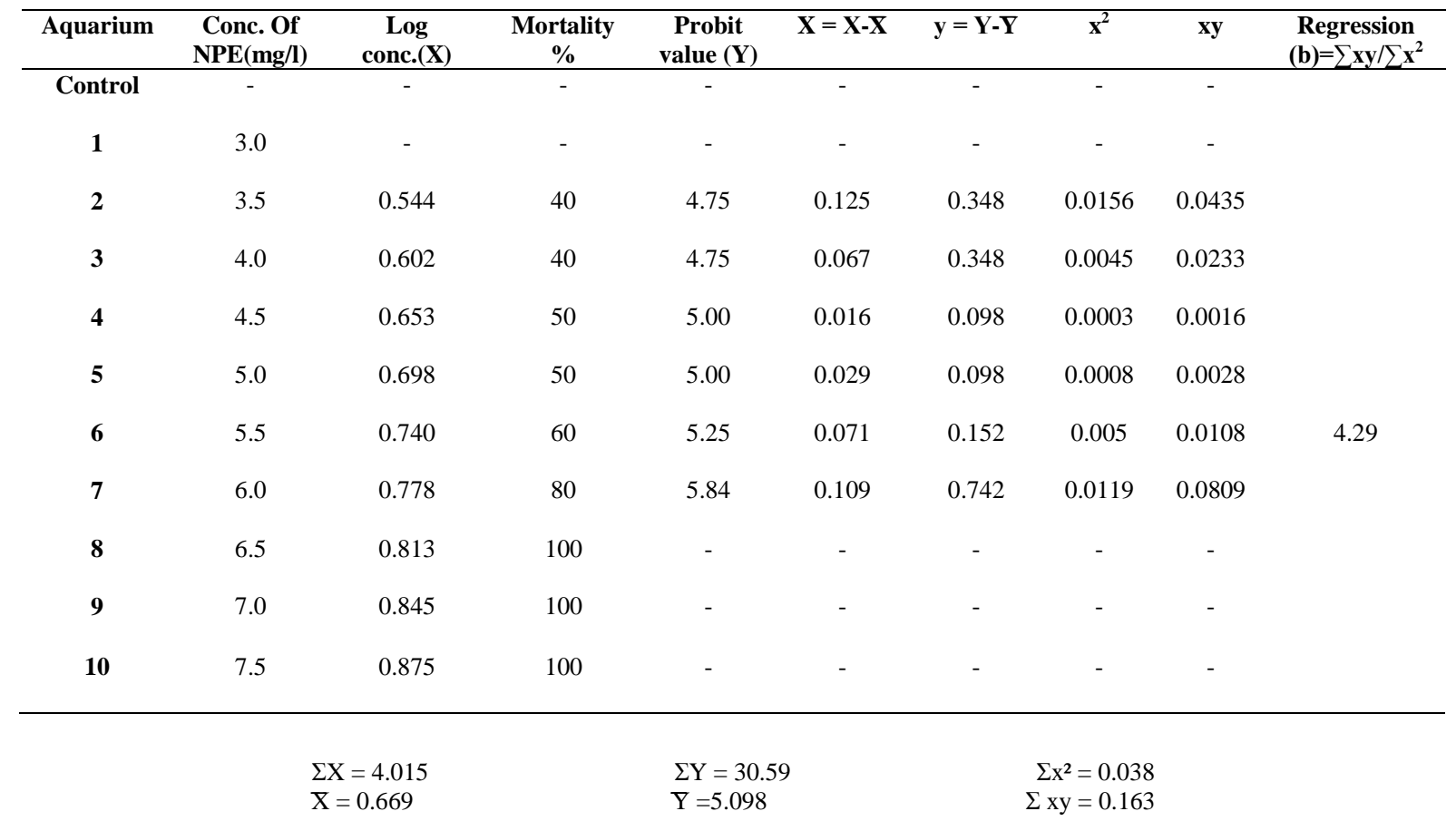

Regression value $(\mathrm{b})=\Sigma \mathrm{XY} / \Sigma \mathrm{X}^{2}=4.29$

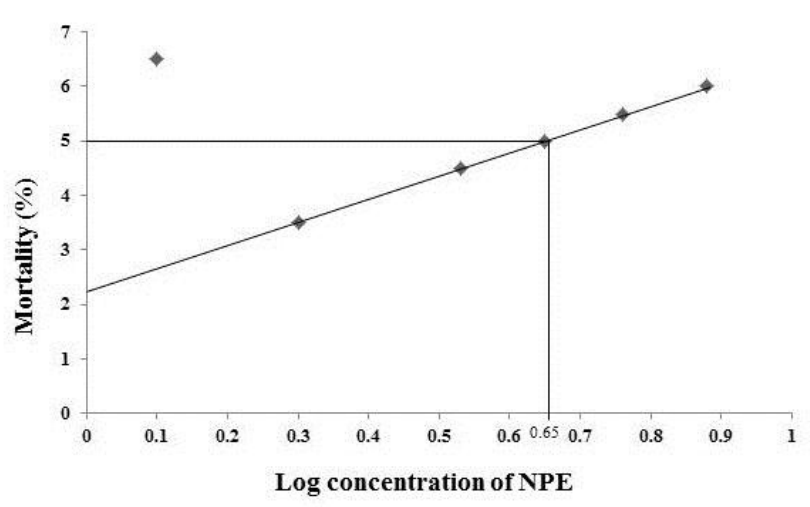

Figure 1. Linear regression curve of log concentration and empirical probit value of mortality response of Labeo bata after 96 hours exposure to NPE.

\section{Acute toxicity}

The mortality responses of fishes were increased with the increasing of time and concentration of NPE. The lethal criteria of $\mathrm{LC}_{10}$ to $\mathrm{LC}_{90}$ values were observed in the $24 \mathrm{~h}, 48 \mathrm{~h}, 72 \mathrm{~h}$ and $96 \mathrm{~h}$ time span during the exposure of NPE represented in the table 
2. The median lethal concentration value of NPE was determined as $4.90 \mathrm{mg} \mathrm{L}^{-1}, 4.79 \mathrm{mg} \mathrm{L}^{-1}, 4.68 \mathrm{mg} \mathrm{L}^{-1}$ and $4.47 \mathrm{mg} \mathrm{L}^{-1}$ at $24 \mathrm{~h}, 48 \mathrm{~h}, 72 \mathrm{~h}$ and $96 \mathrm{~h}$ duration respectively.

Table 2. Acute toxicity test of NPE to the fish Labeo bata in the different time period

\begin{tabular}{|c|c|c|c|c|}
\hline \multirow[b]{2}{*}{ Criteria level } & \multicolumn{4}{|c|}{ Lethal concentration $\left(\mathrm{mg} \mathrm{L}^{-1}\right)$} \\
\hline & 24 hours & 48 hours & 72 hours & 96 hours \\
\hline $\mathrm{LC}_{10}$ & 3.39 & 3.24 & 3.55 & 2.29 \\
\hline $\mathrm{LC}_{20}$ & 3.89 & 3.72 & 3.89 & 2.82 \\
\hline $\mathrm{LC}_{30}$ & 4.27 & 4.07 & 4.17 & 3.39 \\
\hline $\mathrm{LC}_{40}$ & 4.57 & 4.47 & 4.37 & 3.89 \\
\hline $\mathrm{LC}_{50}$ & 4.90 & 4.79 & 4.68 & 4.47 \\
\hline $\mathrm{LC}_{60}$ & 5.25 & 5.13 & 4.90 & 5.01 \\
\hline $\mathrm{LC}_{70}$ & 5.62 & 5.50 & 5.13 & 5.75 \\
\hline $\mathrm{LC}_{80}$ & 6.31 & 6.17 & 5.50 & 6.76 \\
\hline $\mathrm{LC}_{90}$ & 7.08 & 7.08 & 6.03 & 8.71 \\
\hline
\end{tabular}

\section{Behavioural changes of fish with acute toxicity}

At the time of experiment, some behavioural alterations were observed with the exposure of NPE (Table 3). Initially, the fishes were stopped movement and persisted in stagnant position by sudden changes in the aquarium environment. After one hour the fishes were moved rapidly like erratic swimming with hyper excitation. In higher concentration, jumping of fishes was observed in the aquarium. Also, suffocation, opening of mouth and gill were followed after 24 hours in respectively higher concentration. Upward and downward movement was observed through the wall of aquarium. In exposed fishes, excessive mucous secretion was followed all over the body surface with compared to control group. Then the fishes slowly become restless due to loss of excessive energy. Finally, fishes were swimming at the bottom of aquarium due to complete loss of balance and some fishes were gulping before death.

Table 3. Semi quantative scoring of behavioural modification throughout the experimental period with the effect of NPE

\begin{tabular}{|c|c|c|c|c|c|c|c|}
\hline $\begin{array}{l}\text { NPE Conc. } \\
\left(\mathrm{mg} \mathrm{L}^{-1}\right)\end{array}$ & Suffocation & $\begin{array}{c}\text { Erratic } \\
\text { swimming }\end{array}$ & $\begin{array}{c}\text { Opening of } \\
\text { mouth and } \\
\text { gill }\end{array}$ & $\begin{array}{l}\text { Lethargic } \\
\text { movement }\end{array}$ & $\begin{array}{c}\text { Downward } \\
\text { movement }\end{array}$ & $\begin{array}{c}\text { Upward } \\
\text { movement }\end{array}$ & $\begin{array}{c}\text { Gulping } \\
\text { before death }\end{array}$ \\
\hline 3.0 & - & ++ & + & - & - & - & - \\
\hline 3.5 & + & + & + & - & - & ++ & ++ \\
\hline 4.0 & ++ & ++ & ++ & + & + & ++ & ++ \\
\hline 4.5 & +++ & +++ & ++ & ++ & + & + & +++ \\
\hline 5.0 & ++ & +++ & + & + & ++ & ++ & +++ \\
\hline 5.5 & +++ & ++ & +++ & +++ & + & + & +++ \\
\hline 6.0 & ++ & +++ & ++ & ++ & + & + & +++ \\
\hline 6.5 & +++ & +++ & ++ & ++ & + & ++ & +++ \\
\hline
\end{tabular}

Note: The increase or decrease in the level of behavioural parameters is shown by maximum numbers $(+++)$, moderate number $(++)$ and minimum number $(+)$ of fishes in each aquarium. The normal behavioural condition indicates $(-)$ sign.

\section{DISCUSSION}

Acute toxicity of a chemical varies from species to species, age, state of maturity of the organism and due to water parameters. The water parameters such as $\mathrm{pH} 7.58 \pm 0.2$, dissolve oxygen content $6.76 \pm 0.11 \mathrm{mg} \mathrm{L}^{-1}$, total alkalinity $162.08 \pm 1.56 \mathrm{mg} \mathrm{L}^{-1}$ and total hardness $165.1 \pm 2.18 \mathrm{mg} \mathrm{L}^{-1}$ that maintained during the experiment were within the limit of carp culture [18]. Nonylphenol and its derivatives was widely used compound and common aquatic contaminant. Nonylphenol ethoxylate showed acute toxicity and it is also able to mimic important hormone resulting in the disruption of several processes by interfering with the signals that control the overall physiology of the organism.

Nonylphenol indicated to be toxic in fish at a concentration between 17-3000 $\mu \mathrm{g} \mathrm{L}^{-1}$ [19]. Toxicity information of nonylphenol (NP) in fish species is limited to acute toxicity data which vary from species to species, for example $96 \mathrm{~h}$ LC 50 value of NP for 
fathead minnow is $0.135 \mathrm{mg} \mathrm{L}^{-1}$ [10], while for Japanese medaka $96 \mathrm{~h} \mathrm{LC}_{50}$ value is $1.4 \mathrm{mg} \mathrm{L}^{-1}$ [11]. The values of LC 50 range between 135 to $1400 \mu \mathrm{g} \mathrm{L}^{-1}$ on various fish species depending upon test condition $[10,11,20]$. The median lethal concentration value $\left(\mathrm{LC}_{50}\right)$ of NP for adult rosy barb was $1.72 \mathrm{mg} \mathrm{L}^{-1}$ at 96 hours [21]. The $\mathrm{LC}_{50}$ value of nonylphenol was observed as 0.85 $\mathrm{mg} \mathrm{L}^{-1}$ (male) and $0.87 \mathrm{mg} \mathrm{L}^{-1}$ (female) in medaka for $72 \mathrm{~h}$ [22]. In case of Oreochromis mossambicus, the LC $\mathrm{L}_{50}$ value of NP was reported as $1.5 \mathrm{mg} \mathrm{L}^{-1}$ through probit analysis method [23]. However, 96 hours $\mathrm{LC}_{50}$ value of Cichlid fish was $0.89 \mathrm{mg} \mathrm{L}^{-1}$ on the basis of Probit analysis method [12]. In aquatic toxicology if $\mathrm{LC}_{50}$ value of a chemical is less than $1.0 \mathrm{mg} \mathrm{\textrm {L } ^ { - 1 }}$ is highly toxic and if between 1.0-10.0 $\mathrm{mg} \mathrm{L}^{-1}$ it is moderately toxic [24]. In the present study, 96 hours median lethal concentration $\left(\mathrm{LC}_{50}\right)$ value of nonylphenol ethoxylate for adult Labeo bata was estimated to be $4.47 \mathrm{mg} \mathrm{L}^{-1}$ that suggests $\mathrm{NPE}$ was moderately toxic to the fish, Labeo bata.

The behaviour of aquatic organisms are recently growing field in toxicological point of view which correlate to the physiology and ecology of an organisms to their environment. Behavioural toxicology may also have biological significance to the morphological and physiological adaptation in an ecosystem. Moreover, behaviour is also important to adjust external and internal stimuli of an organism to their changing environment. Fish behaviour is very helpful to assessment of ecosystem.

It was reported that the changes of behaviour of fish occurred due to chronic exposure to nonylphenol at $1.0 \mathrm{mg} \mathrm{L}^{-1}$ [25]. Sublethal effect of NP shows loss of equilibrium, lethargy and haemorrhagic alteration in fathead minnows after exposure to $187 \mu \mathrm{g} \mathrm{L}^{-1}$ for $96 \mathrm{~h}$ [10]. The shoaling behaviour, less competition of food resources and attack by other fishes were showed by the exposure of nonylphenol in Rainbow trout [26]. The changes in locomotion activity and starting of aggressive behaviour were reported in both male and female Zebra fishes when long term exposed to nonylphenol [27]. Erratic swimming followed by restricted movements, haemorrhage in body surface, loss of equilibrium and reddening of fin were followed in Etroplus maculatus after exposure to bisphenol A [28]. However, the swimming behaviour was increased in Eurytemora affinis by the exposure of sublethal concentration of nonylphenol [29]. In the present study the behaviour was observed in control and treatment group of fishes throughout the experiment period. The semi quantitative scoring of behaviours like suffocation, erratic swimming and gulping before death were followed in maximum from other behaviour that was emphasize the stress physiology of fishes by the exposure of NPE. The pattern of semi quantitative scoring helps to understand the behaviour of $L$. bata goes to concentration dependent manner to NPE.

\section{CONCLUSION}

The median lethal concentration of NPE was estimated $24 \mathrm{~h}, 48 \mathrm{~h}, 72 \mathrm{~h}$ and $96 \mathrm{~h} \mathrm{LC}_{50}$ value as $4.90 \mathrm{mg} \mathrm{L}^{-1}, 4.79 \mathrm{mg} \mathrm{L}{ }^{-1}, 4.68 \mathrm{mg}$ $\mathrm{L}^{-1}$ and $4.47 \mathrm{mg} \mathrm{L}^{-1}$ respectively for the Indian minor carp Labeo bata. According to its acute toxicity values, NPE was moderately toxic to the fish Labeo bata. The study contributes additional confirmation to the assessment of fish behaviour can establish a highly sensitive method to specify the toxic effect of NPE. This toxic threat of NPE should be taken in concern at the time of discharge in water body or fish habitat.

\section{ACKNOWLEDGEMENT}

Thanks to give a platform to the financial assistant of the University Grants Commission, New Delhi from Rajiv Gandhi National Fellowship (RGNF) to Kousik Roy. Authors are grateful to the Head of the Department of Zoology, Visva-Bharati (A central University), Santiniketan for providing with all laboratory and infrastructural facilities.

\section{REFERENCES}

[1] H.B. Lee, "Review of analytical methods for the determination of nonylphenol and related compounds in environmental samples", Water Quality Research Journal of Canada, Vol. 34, pp. 3-35, 1999.

[2] S.S. Talmage, "Environmental and Human Safety of Major Surfactants", Lewis Publishers, USA, 1994.

[3] M.A. Blackburn, M.J Waldock, “Concentrations of alkylphenols in rivers and estuaries in England and Wales", Water Research, Vol. 29, Issue. 7, pp. 1623-1629, 1995.

[4] M. Ahel, W. Giger, M. Koch, "Behavior of alkylphenol polyethoxylate surfactants in the aquatic environment-I.Occurrence and transformation in sewage treatment", Water Research, Vol. 28, pp. 1131-1142, 1994.

[5] M. Ahel, W. Giger, C. Schaffner, "Behaviour of alkylphenol polyethoxylate surfactants in the aquatic environment. II. Occurrence and transformation in rivers", Water Research, Vol. 28, Issue. 5, pp. 1143-1152, 1994.

[6] C.R. Tyler, S. Jobling, J.P. Sumpter, "Endocrine disruption in wildlife: a critical review of the evidence", Critical Reviews in Toxicology, Vol. 28, pp. 319-361, 1998.

[7] C.L.G. Rivero, A.C. Barbosa, M.N. Ferreira, J.G. Dorea, C.K. Grisolia, "Evaluation of genotoxicity and effects on reproduction of nonylphenol in Oreochromis niloticus (Pisces: cichlidae)”, Ecotoxicology, Vol. 17, pp. 732-737, 2008.

[8] S.L. O'Halloran, K. Liber, J.A. Gangl, M.L. Knuth, "Effects of repeated exposure to NP on the zooplankton community in littoral enclosures", Environmental Toxicology and Chemistry, Vol. 18, pp. 386-393, 1999. 
[9] R.C. Hale, C.L. Smith, P.O. De Fur, E. Harvey, E.O. Bush, M.J. La Guardian, G.G. Vadas, “Nonylphenols in sediments and effluents associated with diversewastewater outfalls", Environmental Toxicology and Chemistry, Vol. 19, Issue. 41, pp. 946-952, 2000.

[10] G.W. Holcombe, G.L. Phipps, M.L. Knuth, T. Felhaber, "The acute toxicity of selected substituted phenols benzenes and benzoic acid esters to fathead minnows, Pimephales promelas", Environmental Pollution Series A, Vol. 35, pp. 367-381, 1984.

[11] K. Yoshimura, "Biodegradation and fish toxicity of nonionic surfactants", Journal of the American Oil Chemists' Society, Vol. 63, pp. 15901596, 1986.

[12] K.P. Asifa, P.V. Vidya, K.C. Chitra, "Assessment of median lethal concentration (LC50 - 96h) and behavioural modification of nonylphenol in the Cichlid fish, Etroplus maculatus (Bloch, 1795)”, International Journal of Advanced Life Sciences, Vol. 9, Issue. 2, pp. 190-195, 2016.

[13] A.M. Soto, H. Justicia, J.W. Wray, C. Sonnenschein, "p-Nonylphenol: an estrogenic xenobiotic released from 'modified' polystyrene", Environmental Health Perspectives, Vol. 92, pp. 167-172, 1991.

[14] S. Jobling, J.P. Sumpter, "Detergent components in sewage effluent are weakly oestrogenic to fish: an in vitro study using rainbow trout (Oncorhynchus mykiss) hepatocytes", Aquatic Toxicology, VOL. 27, pp. 361-372, 1993.

[15] T. Christiansen, B. Korsgaard, A. Jespersen, "Effects of nonylphenol and 17b-oestradiol on vitellogenin synthesis, testicular structure and cytology in male eelpout Zoarces viviparous", Journal of Experimental Biology, Vol. 201, pp. 179-192, 1998.

[16] D.J. Finney, "Probit Analysis", Cambridge University Press, Cambridge, England, pp. 333, 1971.

[17] APHA, "Standard Methods for the Examination of Water and Wastewater 20th Edition", United Book Press, Maryland, United States, 1998.

[18] V.G. Jhingran, "Fish and Fisheries of India", Hindustan Publishing Corporation, India, pp. 727, 1991.

[19] M.R. Servos, "Review of the aquatic toxicity, estrogenic responses and bioaccumulation of alkylphenols and alkylphenol polyethoxylates", Water Quality Research Journal of Canada, Vol. 34, pp. 123-177, 1999.

[20] C.A. Staples, J. Weeks, J.F. Hall, C.G. Naylor, "Evaluation of aquatic toxicity and bioaccumulation of C8-and C9-alkylphenol ethoxylates", Environmental Toxicology and Chemistry, Vol. 17, pp. 2470-2480, 1998.

[21] H. Bhattacharya, Q. Xiao, L. Lun, "Toxicity studies of nonylphenol on rosy barb (Puntius conchonious): A biochemical and histopathological evaluation", Tissue and Cell, Vol. 40, Issue. 4, pp. 243-249, 2008.

[22] S. Kashiwada, H. Ishikawa, N. Miyamoto, Y. Ohnishi, Y. Magara, "Fish test for endocrine disruption and estimation of water quality of Japanese rivers", Water Research, Vol. 36, pp. 2161 - 2166, 2002.

[23] V. Balakrishnan, K.P. Asifa, K.C. Chitra, "Genotoxic potential of nonylphenol in freshwater fish, Oreochromis mossambicus" International Journal of Applied and Natural Sciences, Vol. 3, pp. 81 - 88, 2014.

[24] A.H. Louis, L.W. Diana, H. Patricia, R.S. Elizabeth, "Pesticides and Aquatic Animals", Virginia Cooperative Extension, United States, 1996.

[25] O.H. Spieser, J. Schwaiger, H. Ferling, R.D. Negele, “An introduction to behavioral monitoring-effects of nonylphenol and ethinyl-estradiol on swimming behaviour of juvenile carp", Plenum Publishing Corporation, USA, 2000.

[26] A.J.W. Ward, A.J. Duff, S. Currie, "The effects of the endocrine disrupter 4-nonylphenol on the behaviour of juvenile rainbow trout (Oncorhynchus mykiss)", Canadian Journal of Fisheries and Aquatic Sciences, Vol. 63, pp. 377 - 382, 2006.

[27] J. Xia, C. Niu, X. Pei, "Effects of chronic exposure to nonylphenol on locomotor activity and social behavior in zebrafish (Danio rerio)", Journal of Environmental Sciences, Vol. 22, pp. 1435-1440, 2010.

[28] K.P. Asifa, K.C. Chitra, "Evaluation of LC50 and behavioural responses of bisphenol A in the cichlid fish, Etroplus maculatus", International Journal of Current Research, Vol. 7, pp. 16725 - 16729, 2015.

[29] K. Cailleaud, F.G. Michalec, J.F. Leray, H. Budzinski, J.S. Hwang, F.G. Schmitt, S. Souissi, “Changes in the swimming behavior of Eurytemora affinis (Copepoda, Calanoida) in response to a sub-lethal exposure to nonylphenols", Aquatic Toxicology, Vol. 102, pp. 228 - $231,2011$. 